\title{
SUSTAINABLE BEHAVIOR IN INTERNATIONAL BUSINESS: CORPORATE SOCIAL RESPONSIBILITY FOR MIMICRY OR FOR BUSINESS VALUE?
}

\author{
๑2021 ZUBKOVA A. B., MAKARENKO A. B., MISIUNIA R. M., MAIHUROVA D. S., VODIAKHINA M. O., IHNATOVA A. A.
}

UDC 658.5:005:339.9

JEL: M16; M14; 030

\section{Zubkova A. B., Makarenko A. B., Misiunia R. M., Maihurova D. S., Vodiakhina M. O., Ihnatova A. A. Sustainable Behavior in International Business: Corporate Social Responsibility for Mimicry or for Business Value?}

The paper is aimed at studying different pillars for the development of long-term and short-term strategies in the field of sustainable development and corporate social responsibility. The paper underlines the key differences between the concepts of sustainable development, corporate social responsibility, and ecological, social, and corporate governance. The study aims to highlight the key differences between sustainable behavior and mimicry, i.e. masking the results of companies' activity under the global or local trends in corporate social responsibility. The article focuses on studying key systems for measuring the sustainable development level. Therefore, the results of the world's leading companies have been analyzed according to the main ratings of the sustainable development level. The paper presents the empirical study of the activities of the leading Ukrainian companies in sustainable development, compares their results with those of less successful companies, examines the general situation in Ukraine. Despite the relatively high sustainable development level of the leading players in the Ukrainian market, the companies that had a lower position in the sustainability ranking got lower scores by the key components of evaluating the sustainability level. The research emphasizes the complexity of measuring the sustainable development level of enterprises, and also proposes an integrated system for evaluating the sustainable development level of enterprise, based on a combined list of components used by different analytical companies. The expediency of a more detailed monitoring of the Ukrainian companies' activity, aiming at detecting and counteracting mimicry, is substantiated. The paper proves the necessity to develop a comprehensive measurement system for determining the sustainable development level, which will provide the most accurate evaluation and recommendations for business development.

Keywords: sustainable development (SD), sustainability, sustainable development goals (SDG), corporate social responsibility (CSR), environmental, social and corporate governance (ESG), strategic management.

Fig.: 12. Tabl.: 3. Bibl.: 18.

Zubkova Alina B. - PhD (Economics), Associate Professor, Associate Professor of the Department of International Business and Finance, National Technical University «Kharkiv Polytechnic Institute» (2 Kyrpychova Str., Kharkiv, 61002, Ukraine)

E-mail: zubkova.alina@gmail.com

ORCID: https://orcid.org/0000-0002-4478-181X

Researcher ID: https://publons.com/researcher/3273112/alina-zubkova/

Makarenko Anastasia B. - Senior Lecturer of the Department of International Business and Finance, National Technical University «Kharkiv Polytechnic Institute» (2 Kyrpychova Str., Kharkiv, 61002, Ukraine)

Misiunia Ruslan M. - Postgraduate Student of the Department of International Business and Finance, National Technical University "Kharkiv Polytechnic Institute» (2 Kyrpychova Str., Kharkiv, 61002, Ukraine)

E-mail: rysland1@gmail.com

ORCID: https://orcid.org/0000-0002-3496-3986

Maihurova Daria S. - Postgraduate Student of the Department of International Business and Finance, National Technical University "Kharkiv Polytechnic Institute» (2 Kyrpychova Str., Kharkiv, 61002, Ukraine)

E-mail: dashamaigurova@gmail.com

Vodiakhina Marharyta 0. - Master, Department of International Business and Finance, National Technical University «Kharkiv Polytechnic Institute» (2 Kyrpychova Str., Kharkiv, 61002, Ukraine)

Innatova Anastasiia A. - Master, Department of International Business and Finance, National Technical University «Kharkiv Polytechnic Institute» (2 Kyrpychova Str., Kharkiv, 61002, Ukraine)

УДК 658.5:005:339.9

JEL: M16; M14; 030

зубкова А. Б., Макаренко А. Б., Місюня Р. М., Майгурова Д. С., Водяхіна М. О., Ігнатова А. А. Сталий розвиток в міжнародному бізнесі: корпоративна сочіальна відповідальність для мімікрії чи для чінності бізнесу?

Метою статті є дослідження різних підходів до побудови довгострокової та короткострокової стратегії в контексті сталого розвитку та корпоративної соціальної відповідальності. У статті надано огляд літератури та висвітлено відмінності між концепціями сталого розвитку, корпоративної соціальної відповідальності й екологічного, соціального та корпоративного управління. Надано структурні та характерні відмінності цих концепцій. Дослідження націлене на висвітлення ключових відмінностей між сталою поведінкою та мімікрією - маскуванням результатів діяльності компаній під глобальний тренд корпоративної соціальної відповідальності. Стаття фокусується на дослідженні різних систем оцінки рівня сталого розвитку. Проаналізовано результати діяльності провідних світових компаній згідно з основними рейтингами рівня сталого розвитку. Наведено дослідження діяльності провідних українських компаній, надано порівняння з результатами менш успішних компаній, досліджено загальну ситуацію в Україні. Попри відносно високі показники рівня сталого розвитку провідних гравців українського ринку, компанії, які знаходяться нижче в рейтингу, показують низькі результати за ключовими компонентами оцінки рівня сталості. У статті наголошується на складності процесу оцінки рівня сталого розвитку підприємств, а також запропоновано інтегровану систему оцінки рівня сталого розвитку підприємства, що базується на комбінованому переліку компонентів, які використовуються різними аналітичними компаніями. Надано обгрунтування доцільності більш детального моніторингу діяльності українських компаній, з метою виявлення та протидії мімікрії, а також наголошується на побудові комплексного алгоритму визначення рівня сталого розвитку, який надасть змогу дати якомога точний висновок. 
Ключові слова: сталий розвиток, сталість, чілі сталого розвитку, корпоративна соціальна відповідальність, екологічне, соціальне та корпоративне управління, стратегічне управління.

Рис.: 12. Табл.: 3. Бібл.: 18.

зубкова Аліна Болеславівна - кандидат економічних наук, доцент, доцент кафедри міжнародного бізнесу та фінансів, Національний технічний університет «Харківський політехнічний інститут» (вул. Кирпичова, 2, Харків, 61002, Україна)

E-mail: zubkova.alina@gmail.com

ORCID: $h$ ttps://orcid.org/0000-0002-4478-181X

Researcher ID: https://publons.com/researcher/3273112/alina-zubkova/

Макаренко Анастасія Борисівна - старший викладач кафедри міжнародного бізнесу та фінансів, Національний технічний університет «Харківський політехнічний інститут» (вул. Кирпччова, 2, Харків, 61002, Україна)

Місюня Руслан Михайлович - аспірант кафедри міжнародного бізнесу та фінансів, Національний технічний університет «Харківський політехнічний інститут» (вул. Кирпичова, 2, Харків, 61002, Україна)

E-mail: rysland1@gmail.com

ORCID: https://orcid.org/0000-0002-3496-3986

Майгурова Дар'я Сергіївна - аспірантка кафедри міжнародного бізнесу та фінансів, Національний технічний університет «Харківський політехнічний інститут» (вул. Кирпичова, 2, Харків, 61002, Україна)

E-mail: dashamaigurova@gmail.com

Водяхіна Маргарита Олегівна - магістр, кафедра міжнародного бізнесу та фінансів, Національний технічний університет «Харківський політехнічний інститут» (вул. Кирпичова, 2, Харків, 61002, Україна)

Ігнатова Анастасія Андріївна - магістр, кафедра міжнародного бізнесу та фінансів, Національний технічний університет «Харківський політехнічний інститут» (вул. Кирпичова, 2, Харків, 61002, Україна)

S cientific and technological progress and the impact of anthropogenic factors have exacerbated the environmental situation and socio-economic tensions around the world. Problems of natural resources depletion, environmental pollution, deterioration of human life quality due to the negative impact of environmental factors, decline in the working population, longevous society, decline in global competitiveness, outdated infrastructure, natural disasters, terrorism, environmental problems, lack of natural resources, and lack of active participation in public life require searching for new solutions to solve these problems. The concept of the fifth industrial revolution or Industry 5.0 has become a response to modern global challenges. The development of the Concept of Industry 5.0 has a significant impact on the sustainable development of economies and businesses.

The main idea of the strategy is to solve social problems by integrating digital environment and physical space and, as a result, improving human life quality. Innovations in such a society are convenient and safe, they make people's lives comfortable and fulfilling. According to the "Industry 5.0" strategy, advanced technologies, penetrating into all spheres of life, should lead to the emergence of new business forms and types and thus to sustainable development of enterprises, economic growth of the country as a whole and increase in life quality.

The purpose of our research is to give a detailed description of such a phenomenon in business as corporate social responsibility. In the course of writing this work, we set the following tasks:

1. To determine the role of CSR.

2. To identify the attributes characterizing te CSR as a part of sustainable business in Ukraine and international companies.
The research will use the technique of deep interviewing of a company, as well as the analysis of the international CSR assessment system.

Problem statement: Sustainability is mostly used by businesses as a modern differentiator/attribute. Corporate social responsibility exploits sustainability to attract consumers rather than to change the business environment/eco-system around the business.

H1.0. Sustainability is an attribute of Corporate Social Responsibility.

H1.1. Sustainability is the company's philosophy.

$S^{2}$

ustainability as an attribute of Corporate Social Responsibility is used for marketing communications in international business.

The value system is an important element of corporate responsibility management. Based on the results of the Ukrainian companies survey, the main stimulus for implementing CSR policy is moral compulsion. It should be understood that to implement CSR successfully, the company must first of all create a value system that meets the basic principles of sustainable development.

H2.0. CSR is possible without Sustainable behavior.

H2.1. CSR is impossible without Sustainable behavior. Fig. 1.

The logical framework of the research is shown in

Research methods. In order to determine the top corporate social company in Ukraine, it was decided to look at the existing sustainable development ratings. Thus, Sustainable Ukraine, the official Ukrainian rating was chosen for the study. The paper will consider the top-5 companies that lead the ratings, analyze the actions of the companies that caused their leadership, and study the methodology for compiling these ratings. 


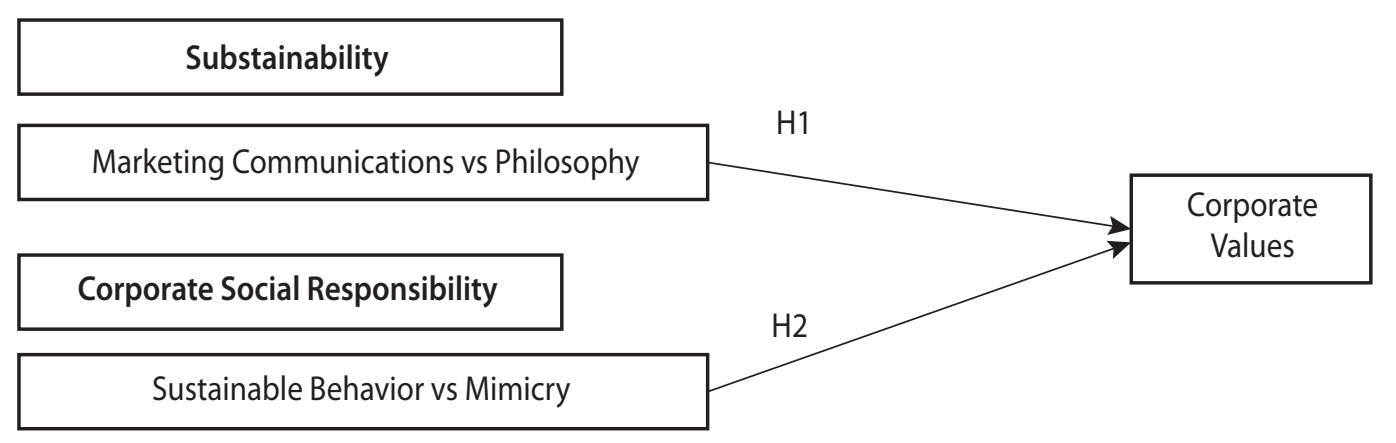

Fig. 1. Logical framework of the research

Besides, to find out the reasons for the existence of mimicry and the transition of companies to CSR, the method of in-depth interviewing of companies will be applied. In connection with the increase in the number of business organizations declaring their commitment to the sustainable development principles, a comparative analysis of the approaches used by foreign and Ukrainian business organizations to interpreted the content and principles of sustainable development and their implementation was carried out. Analysis of approaches to interpreting sustainable development used by Ukrainian companies in practice allows us to identify a number of their characteristic features, as well as to determine the degree of compliance of the Ukrainian business organizations' practices with international and national standards, as well as similar practices of leading organizations in order to assess the degree of involvement of Ukrainian business organizations in sustainable development.

S ustainability is a broad discipline that gives us insight into most aspects of the human world, from business to technology, environment and social sciences. However, the most common definition was suggested by the Brundtland Commission in 1987, which ran as follows: "Sustainable development is development that meets the needs of the present without compromising the ability of future generations to meet their own needs" [1]. The idea of sustainable development in entrepreneurship is primarily presented in connection with the survival of a company. The triple concept of sustainable development is used as a means to expand and develop a basic approach to value creation. A sustainable company focuses on developing knowledge, creativity, analytical skills, and learning in order to exceed current requirements and thus achieve lasting competitive advantage in the future $[2 ; 3]$. Basically, the sustainable development of an enterprise means that every SD requirement is implemented in the company's operations and decisionmaking process [4]. At the general level, sustainable development is often understood as a practical process in which the economy, the environment, and society combine in a sustainable way, in particular by reconciling the conflicts between these three elements [5; 6]. According to Getachew Assefa and Bjorn Frostell [8], an economi- cally sustainable system can produce goods and services on a continuous basis, i. e. using different strategies to optimally use the existing resources so that a responsible and profitable balance can be achieved in the long term.

CSR is reported to have a significant influence on corporate sustainability. In the business context, CSR has emerged as a form of sustainability governance with advantages to the economic, environmental and social progress. Successful executives know that their longterm success is based on continuously good relations with a wide range of individuals, groups and institutions. Smart firms know that business can't succeed in societies that are failing - whether this is due to social or environmental challenges, or governance problems. In as much as these organizations are returning back to the society, do they benefit from this investment in terms of increased profit, satisfy and retain customers and increase their market share.

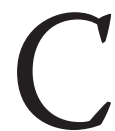
orporate sustainability reporting, although still unregulated, is evolving. A growing percentage of investors are demanding comparable metrics around material issues, which means CSR is only going to take you so far. Without CSR, there would be no ESG, but the two are far from interchangeable. While CSR aims to make a business accountable, ESG criteria make its efforts measurable. With CSR activities varying massively between businesses and sectors, there is a lack of comparable metrics available. ESG activity, on the other hand, is generally quantifiable to a far greater degree.

For many businesses, CSR has never gone beyond being an add-on to their main purpose and overall direction, a footnote in the annual report, an activity that is allocated half a day of effort and focus once per year. At worst, it has become a marketing tool, allowing an organization to say what it is doing well without having to back up its claims or talk about areas where it may be failing. To the immense frustration of CSR professionals, it has failed to live up to its promise, largely because it has far more breadth than depth in its scope [17]. So, unfortunately, in recent years, we have seen companies resort to an imitation of corporate social responsibility in an attempt to "catch up" with competitors, as well as in an effort to keep up with trends, thereby attracting new 
customers. This concept is called mimicry. The notion of mimicry suggests that organizations often undertake convergent transformation courses to appear legitimate in their institutional spheres [8]. Organizations seek to replicate successful partners in their business environment in order to be legitimate, thereby reaping the same benefits at a lower cost. As a consequence, this leads to institutional isomorphism [9-11].

$\mathrm{B}$ ehavioral mimicry is also called modeling (which means that firms model themselves after their peers), and it occurs through a variety of mechanisms. Imitation for legitimation will only appear if the imitated organizations are perceived to be significantly successful in accordance with the values maintained in this area [12]. Firms will imitate other organizations within their industry [13]. However, the simulated firms must be identical in complexity or advanced. When imitated firms are identical in complexity or considered to be advanced, a national culture is likely to emerge. In this respect, the legitimacy of the mimicry isomorphism is determined by culture. It seems that socially responsible behavior is viewed as a must-have media element of the modern business organization, but the benefits it can bring remain neglected.

Generally, sustainable behavior is a behavior that encompasses peoples' values, norms and beliefs, dutifulness in deliberate actions focused to providing the wellbeing for all humans, including present and future generations [14].

The Institute for Business Social Responsibility is a system of formal and informal norms and rules that directly affect the main activities of business organizations, their choice of strategic and situational decisions, determine their relationships with stakeholders, establish a framework for making business decisions, and provide a number of institutional advantages [15].

Responsible business behavior, in fact, benefits society and removes the negative consequences it can have on society, people and the planet. This view of business can help decision-makers make more responsible decisions by ensuring a balance between considerations of social and environmental impact and those of financial gain. Being responsible also means being resilient. This implies that corporate social responsibility is an integral part of sustainable development. However, one cannot deny the existence of such a big, in our opinion, problem as mimicry. In pursuit of increasing profits, companies resort to creating an illusion of social responsibility [16].

The intensive development of the communication network and the increase in the target audience have caused entrepreneurs to find a reliable, affordable and relatively cheap tool for disseminating information concerning their social obligations to stakeholders. Money and time costs for data transmission were reduced to the lowest possible value, while the form of presenting information was extremely simplified [17]. Under these conditions, businesses are tempted to abandon the principles of sustainable development in favor of information mimicry, creating an illusion of social activity, and providing formal signs of business social responsibility. Imitation of socially responsible behavior causes significant damage to society in the form of information asymmetry, competitive advantages received by unscrupulous business organizations, lack of business contribution to sustainable development within the framework of the shared value concept. This phenomenon leads to the replacement of long-term goals with the short-term ones, which does not lead to sustainable development and sustainability of individual organizations [18].

Large corporations recognize the importance of being socially active and take many steps to earn the status of "socially active" or "socially responsible". Whole structures are being created to work in the social sphere. Every Western firm attached to its dignity provides its website with detailed information on its social activities. Ukrainian companies have recently begun to adhere to this trend. Needless to say, a well-thought-out social policy influences not only the creation of a favorable attitude towards the company, but also gives an economic effect. In other words, companies are introducing Corporate Social Responsibility (CSR) into their activities. So what is CSR? In simple words, CSR encompasses all the practices used by companies in order to uphold the principles of sustainable development. And what does it mean to be a sustainable or responsible organization? It means that companies need to be economically viable, have a positive impact on society, and respect and preserve the environment.

CSR in Ukraine is at the development stage, as it continues to focus on a closer circle of stakeholders, i.e. the state, owners and staff. A wider range of stakeholders, such as local communities, suppliers and others, is not yet a systemic feature. CSR in Ukraine is a voluntary contribution of the private sector to community development through charity and the social investment mechanism. Social investment in Ukraine is facing significant problems associated with institutional imperfections. This approach impairs the country's competitiveness in foreign markets.

A ccording to a poll conducted by the Center for Social Expertise of the Institute of Sociology of the National Academy of Sciences of Ukraine and the Intellectual Perspective Charitable Foundation, which involved 811 enterprises of various sizes, forms of ownership and areas of activity, business structures position their responsibilities as follows:

+ implementation of social projects: $60 \%$ of respondents are positive and consider it useful for society as a whole; a quarter showed "neutrality"; $5 \%$ of respondents reported as having a negative attitude, and assessing such activities as "wasted time and resources"; 
+ in assessing the probability of their participating in the implementation of social projects: $4 \%$ of respondents noted the lack of opportunities for business structures to implement social projects; a third believe that this possibility exists for all business organizations; half of the respondents are convinced that this is possible, but only in some companies; assistance to the incapacitated or elderly people, to children with special needs, the disadvantaged ranked 60\%; health care took $58 \%$; education - $50 \%$; ecology - $39 \%$; science $30 \%$; culture and art $-22 \%$.

We have studied in detail the report titled "Development of CSR in Ukraine 2010-2018," which was provided by this organization.

$\mathrm{T}$ The study is aimed at revealing the latest trends, barriers and prospects for developing corporate social responsibility in Ukraine. The overall study sample comprised enterprises and organizations from 24 regions of Ukraine and the city of Kyiv, except for enterprises located in the territory of the Autonomous Republic of the Crimea and the areas of Donetsk and Luhansk which are out of governmental control. During the study, people of the following professions were interviewed: head of an organization - 154, commercial or executive director - 24, deputy director - 19, PR / communications specialist - 6, head of HR department - 24, marketer - 3, other - 19, accountant - 117, department head / manager - 29, engineer - 5. Among the motives leading to the CSR policy implementation, the first place is given to moral compulsion (Fig. 2). Moral compulsion has already been the main motivator for the CSR policy implementation for many years.
Those who do not implement social responsibility policies believe that their company cannot afford it financially. Really, for many companies, financial problems are extremely relevant, but, in our opinion, the stereotype that CSR projects need a lot of money also plays a great role here.

Among the other common reasons for non-implementing CSR are the following ones: companies have never thought about social responsibility; lack of incentives from the outside states; belief that CSR is a function of the state, not business (Fig. 3). Many researchers believe that the distribution of answers to this question may indicate that representatives of Ukrainian companies have little knowledge of the nature and advantages of CSR implementation.

$\mathrm{U}$ nfortunately, the trend of the previous years was that CSR implementation went too slowly at the managerial level. Only half of the companies studied implement CSR policy, have a social responsibility strategy (policy), and have doubled the budget share for implementing social responsibility programs / measures. Unfortunately, without understanding why it is necessary to conduct socially responsible activities, nothing will work properly. This suggests the conclusion that values formation is extremely important for successfully carrying out CSR activities. Now, let's take a closer look at the methodology of the official rating of sustainable development in Ukraine titled «Sustainable Ukraine», and analyze the results in support of hypothesis 1.1.

Sustainable Ukraine rating is the first professional rating of corporate sustainability within Ukrainian companies, based on leading international practices, with a particular focus placed on the investment appeal of a

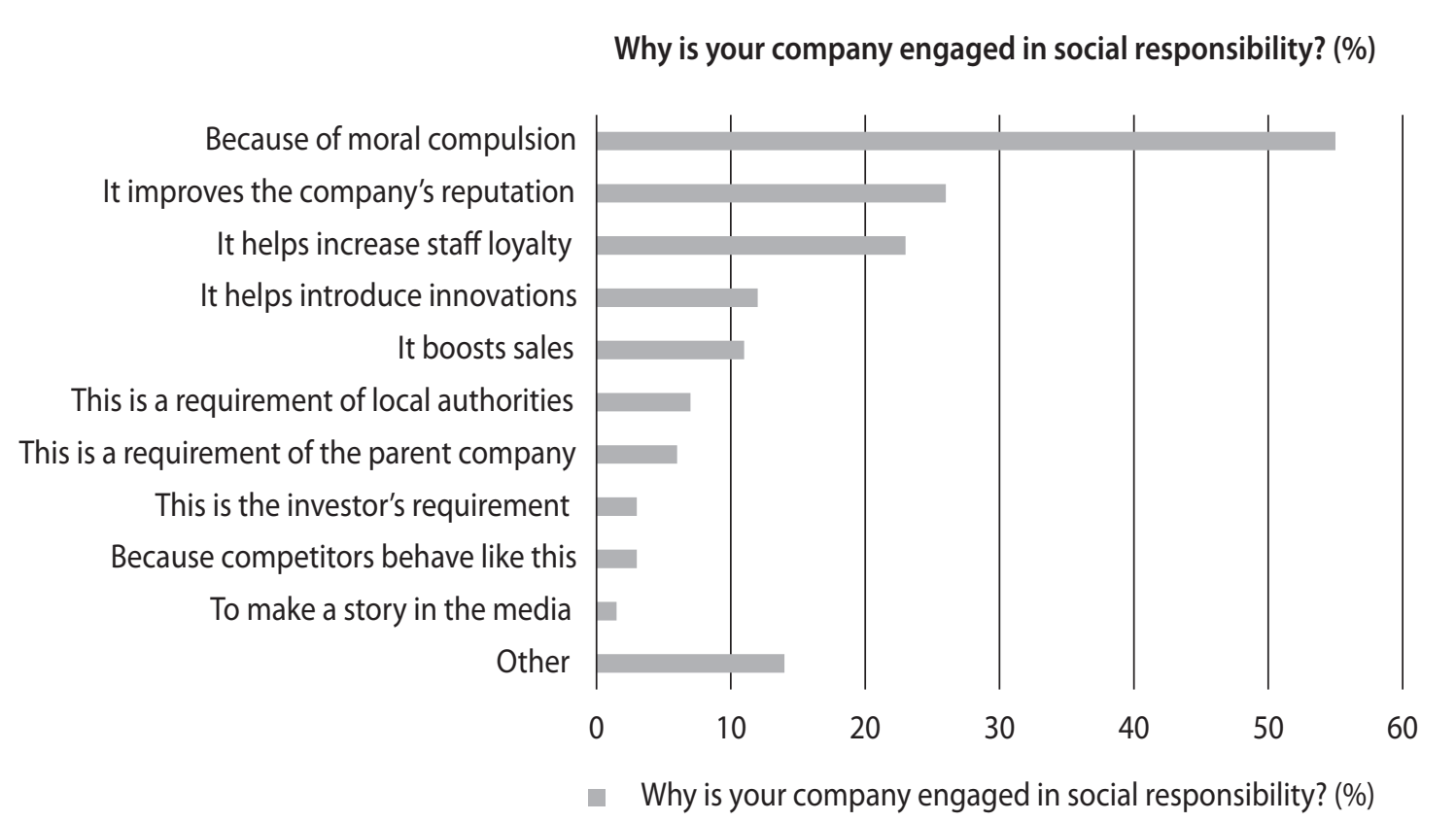

Fig. 2. Reasons why the company implemented CSR 
In your opinion, why isn't social responsibility

program/activity topical for your company?

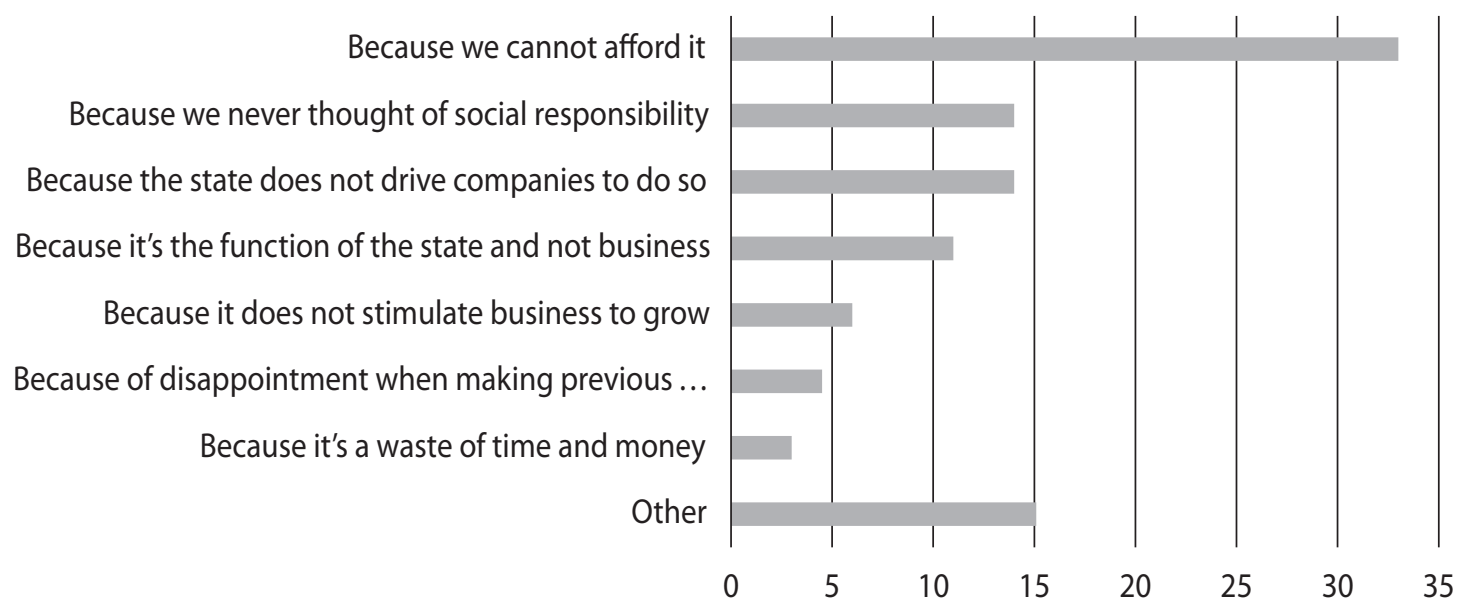

- In your opinion, why isn't social responsibility program/activity topical for your company?

Fig. 3. Reasons why companies do not implement CSR

company. Evaluation is based on a questionnaire that is filled out by each respective participating party. The questionnaire is clearly structured and contains $100+$ indicators grouped into key spheres: financial, economic, social, and environmental and corporate governance. The evaluation accuracy depends on the plenitude and reliability of the answers provided by a participant. Unfortunately, in such countries as Ukraine, provided that the financial factor comes to the fore, the development of mimicry is provoked. Companies only pretend to be in line with all other sustainable development factors, imitating corporate social responsibility. In pursuit of profit, corporations do not create the company's philosophy from the inside, but simply take actions "for show."

7 he first places in the rating are occupied by stateowned companies: due to their production volumes, they pay much more taxes than private companies do, and, accordingly, are ahead of latter in the rating. But let's see if the financial factor is really so important. As we pointed out earlier, the UN system works on all the three components of sustainable development, name; economic, social and environmental ones. It is the unifying platform for integration, action on sustainable development and follow-up and review. Each component consists of a specific set of different aspects and characteristics. The United Nations describes each component in such a way:

+ Social components (workers' safety and health: impact on local communities, life quality; benefits for disadvantaged groups);

+ Economic components (creation of new markets and opportunities for sale growth; cost reduction through efficiency and improvements; creation of additional value);
+ Environmental components (reduced waste, effluent generation, emission into environment; reduced impact on human health; use of renewable raw materials; elimination of toxic substances).

$\mathrm{D}$ uring the analysis and literature review, these components were compared and, in some cases, even matched with the 17 SDG goals. Each of them can be directly attached to the three components of sustainable development (economic, environmental and social). The relationship between goals and components are given in $T b l .1$.

To prove our hypothesis 2.0 or 2.1 and understand whether it is possible for CSR to exist without sustainable behavior, we have to check the situation in the global market.

A large sample of companies from Sustainable Development Ratings was obtained through the process of data analysis. In order to reduce the number of components, a screening based on 2 ratings was made. In this research «Corporate Knights Global 100» and DJSI ratings were used. It is important to mention that both ratings are international and multispectral, but their methodology is different. These ratings were used for research purposes since one of them is qualitative, and the other is quantitative.

The «Corporate Knights Global 100» uses a purely quantitative methodology to determine inclusion in the ranking. The «Global 100» starting universe automatically considers all firms with a market capitalization of at least $\$ 1$ billion. The firms are then put through numerous screenings to test for key information, including; overall sustainability disclosure rate and sustainability disclosure rate versus GICS sector peers, a financially based Piotroski F-score to ensure financial stability, and fines, 
SDG and components of Sustainable Development

\begin{tabular}{|c|c|c|}
\hline & SDG: Sustainable Development Goals & Sustainable development components (UN Global Compact) \\
\hline \multirow{7}{*}{$\overline{\frac{\pi}{2}}$} & Goal 1: Zero poverty & \multirow{2}{*}{ 1. Workers' safety and health } \\
\hline & Goal 2: Zero hunger & \\
\hline & Goal 3: Good health and well-being & \multirow{3}{*}{ 2. Impact on local communities and life quality } \\
\hline & Goal 4: Quality education & \\
\hline & Goal 5: Gender equality & \\
\hline & Goal 6: Clean water and sanitation & \multirow{2}{*}{ 3. Benefits for disadvantaged groups } \\
\hline & Goal 16: Peace, justice, strong institutions & \\
\hline \multirow{5}{*}{ 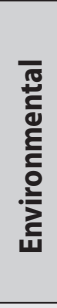 } & Goal 7: Affordable and clean energy & $\begin{array}{l}\text { 4. Reduced waste, effluent generation, emission into the envi- } \\
\text { ronment }\end{array}$ \\
\hline & Goal 12: Responsible consumption and production & \multirow{2}{*}{ 5. Reduced impact on human health } \\
\hline & Goal 13: Climate action & \\
\hline & Goal 14: Life below water & 6 Use of renewable raw materials \\
\hline & Goal 15: Life on land & 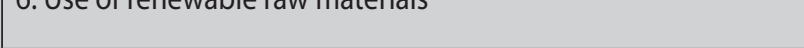 \\
\hline \multirow{5}{*}{ 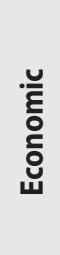 } & Goal 8: Decent work and economic growth & \multirow{2}{*}{ 7. Creation of new markets and opportunities for sale growth } \\
\hline & Goal 9: Industry, innovation, infrastructure & \\
\hline & Goal 10: Reduced inequalities & \multirow{2}{*}{ 8. Cost reduction through efficiency and improvements } \\
\hline & Goal 11: Sustainable cities and communities & \\
\hline & Goal 17: Partnerships for the goals & 9. Creation of additional value \\
\hline
\end{tabular}

\begin{tabular}{|l|l|l|}
\hline \multicolumn{1}{|c|}{ Economic } & \multicolumn{1}{c|}{ Environmental } & \multicolumn{1}{c|}{ Social } \\
\hline $\begin{array}{l}\text { Goal 8: Decent work and economic } \\
\text { growth }\end{array}$ & Goal 7: Affordable and clean energy & Goal 1: Zero poverty \\
\hline $\begin{array}{l}\text { Goal 9: Industry, innovation, infrastruc- } \\
\text { ture }\end{array}$ & $\begin{array}{l}\text { Goal 12: Responsible consumption } \\
\text { and production }\end{array}$ & Goal 2: Zero hunger \\
\hline Goal 10: Reduced inequalities & Goal 13: Climate action & Goal 3: Good health and well-being \\
\hline $\begin{array}{l}\text { Goal 11: Sustainable cities and com- } \\
\text { munities }\end{array}$ & Goal 14: Life below water & Goal 4: Quality education \\
\hline Goal 17: Partnerships for the goals & Goal 15: Life on land & Goal 5: Gender equality \\
\hline & & Goal 6: Clean water and sanitation \\
\hline
\end{tabular}

penalties or settlements paid out by the company for sustainability related violations.

DJSI, vice versa, uses qualitative information. The DJSI set of criteria is used to assess the economic, social, and environmental opportunities of the companies that the DJSI has listed, which are chosen based on the Corporate Sustainability Assessment.

The final study sample has five companies that are mentioned in both ratings. These companies are given in Tbl. 2.

Therefore, the authors selected these companies based on their annual sustainability reports and rated them on a Likert scale. The result is shown in Fig. 4.

This figure proves that in the global market, the top companies are truly performing on the basis of sustainable development goals and UN Global Compact, and don't show any evidence of mimicry. Although, due to the fact that the basic evaluation is often not enough to see the real difference between global sustainable companies (as it is shown in Fig. 4, all of these companies have 5 points in each component, so we cannot definitely name which firm is the first and which one is fifth), we have to understand the mechanism of the evaluation process. This issue will be described in the next parts of this research.

$\mathrm{T}$ he reports of Ukrainian companies, which have leading positions in the rating, were also studied in detail. According to the Sustainable Ukraine rating, they are: Energoatom, Ukrhydroenergo, Kernel, Metinvest, and DTEK.

It is necessary to say that for research purposes we chose only those companies that are originally Ukrainian. The Sustainable Ukraine list also includes some subsidiaries and branch companies: Karlsberg, Coca-Cola 
Final sample of 5 companies that are mentioned in both ratings

\begin{tabular}{|l|l|l|}
\hline \multicolumn{1}{|c|}{ Companies } & \multicolumn{1}{c|}{ DJSI Industry } & \multicolumn{1}{c|}{ GK Industry } \\
\hline Schneider Electric SE & Electrical Components \& Equipment & Industrial Conglomerates \\
\hline UPM-Kymmene Oyj & Paper \& Forest Products & Forestry and Paper Products \\
\hline Cisco Systems Inc & Communications Equipment & Communications Equipment \\
\hline Hewlett Packard Enterprise Co & $\begin{array}{l}\text { Computers \& Peripherals and Office } \\
\text { Electronics }\end{array}$ & Computer Hardware \\
\hline Acciona SA ** & Electric Utilities & Facilities and Construction Services \\
\hline
\end{tabular}

Results of Foreign top-5 sustainable companies

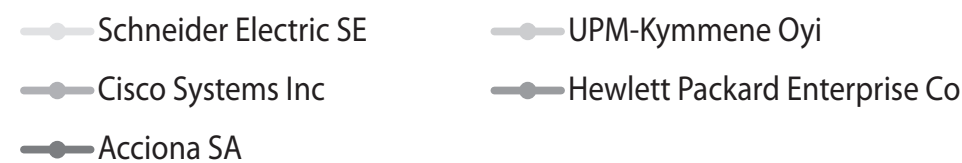

Workers' safety and health

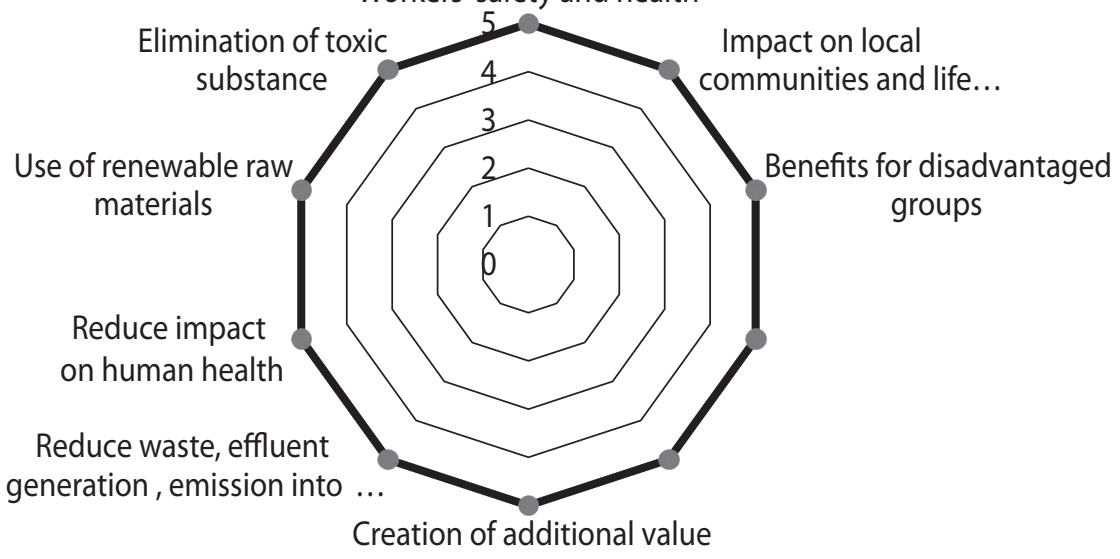

Fig. 4. Evaluation of sustainable development components of the foreign companies

Ukraine, etc. Those companies were not included into our research, because their policies are regulated from their foreign headquarters, so the chances to discover real cases of mimicry are minimal.

In order to make a statement about their sustainable development level, we evaluated their activity on a Likert scale. The parameters were based on the UN Sustainable Development Goals and UN Global Compact. The results are shown in Fig. 5.

7 he results here demonstrate that top Ukrainian companies tend to adhere to sustainable development and real implementation of positive changes, caused by UN Global Compact and Social Development Goals. Unfortunately, this result is far from the ideal point. Unfortunately, based on the results obtained, we can say that companies that are of Ukrainian origin, and are not part of an international corporation, do not fully correspond to their position in the rating. Environmental factors are not respected; many problems are hidden behind the window dressing. For example,
Energoatom still pollutes the environment, storage facilities are almost overflow, work-related accidents occur annually. This indicates that the declared sustainable development strategy is not implemented in practice, or is implemented poorly. At the same time, companies with an already formed philosophy are successfully introducing new projects and coping with the existing problems.

In order to understand the real situation in Ukraine we decided to add another evaluation for bottom- 5 Ukrainian companies from Sustainable Ukraine list. The components were the same, and the following companies were considered: ATB, Tedis, Epicentr-K, Eridon, BaDM.

It is necessary to say that all these companies do operate all over Ukraine and rather widely describe their "sustainable activity" on social media, but still are located on the bottom of this rating. The results are shown in Fig. 6.

As it is shown in Fig. 6, some of the components received low grades. For example, for this set of companies, the worst situation is connected with the elimination of toxic substances that have a huge negative influence on the environment in the long-term perspective. To make a 


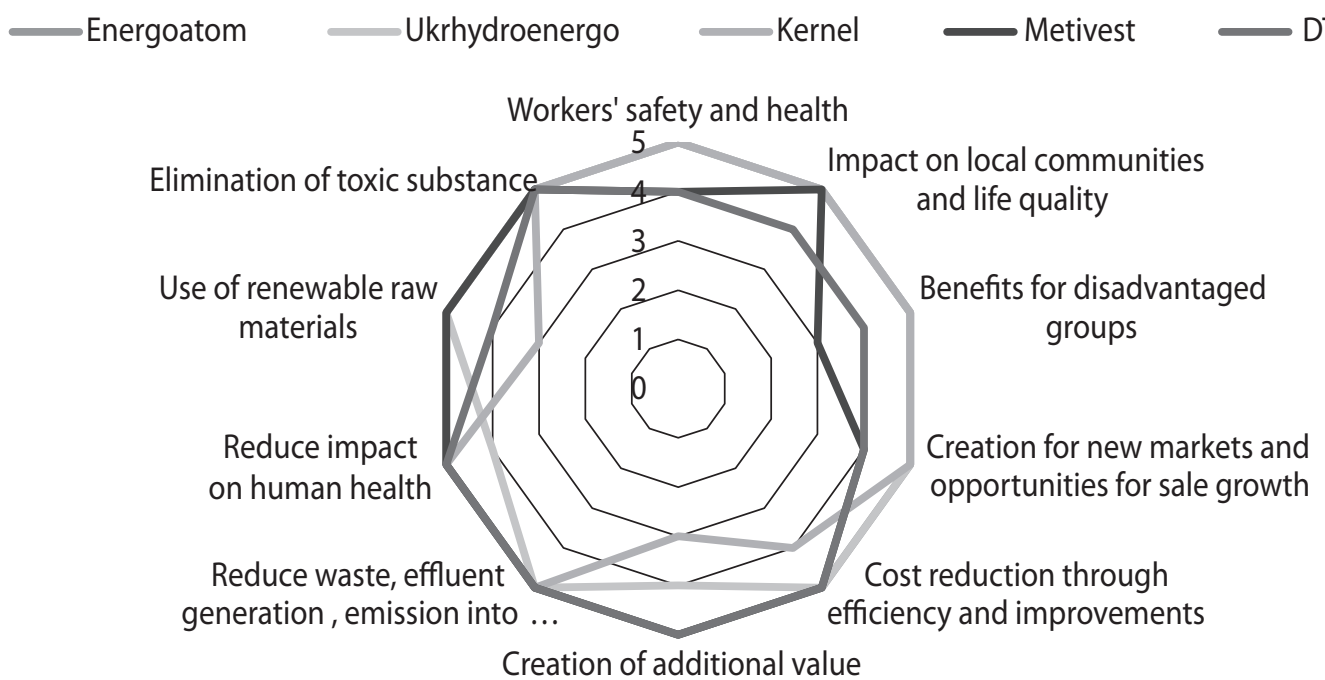

Fig. 5. Evaluation of sustainable development components of top-5 Ukrainian companies

Results of drop-5 Ukrainian sustainable companies
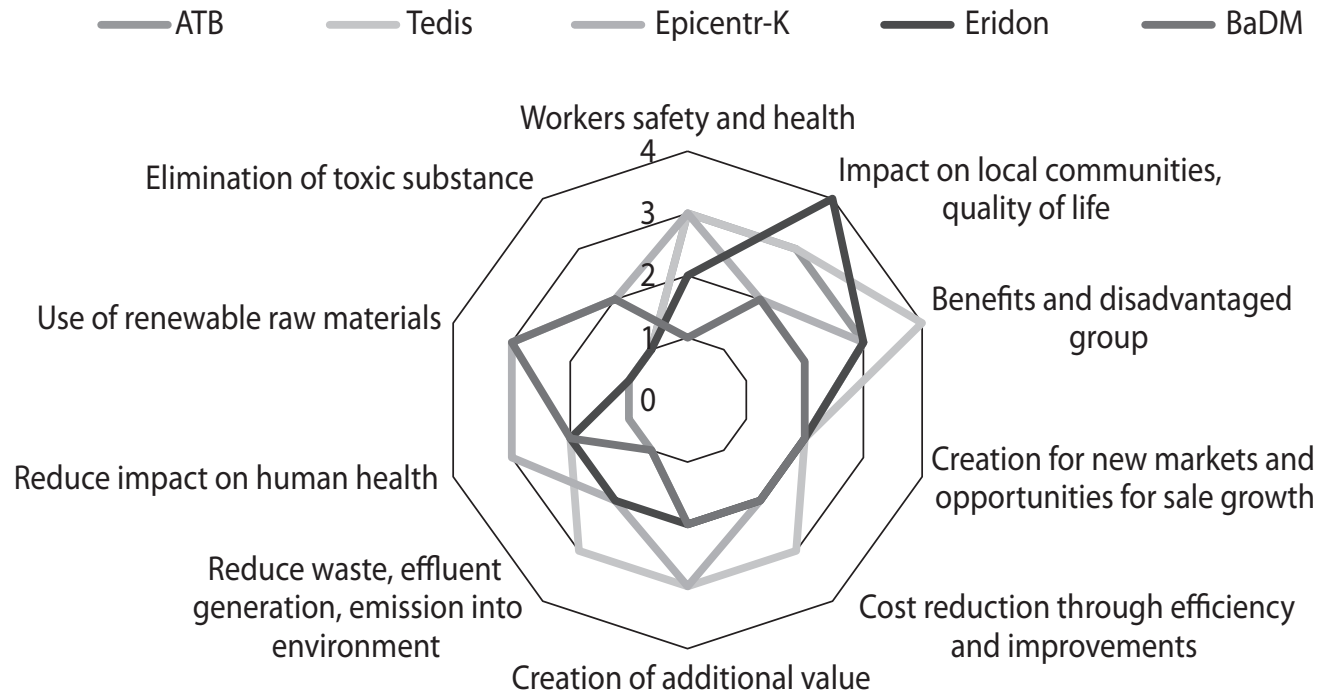

Fig. 6. Evaluation of sustainable development components of bottom-5 Ukrainian companies

statement about the necessity for Ukrainian companies to improve their working processes in terms of sustainable development goals and the UN Global Compact, we can compare our results. The difference between top and bottom 5 Ukrainian companies can be used as a tool for understanding the situation in Ukrainian market and proves that some companies choose to benefit from mimicry in a short-term period. They are making a visual impression they are providing real changes, but in fact, the efforts are only applied to the extent when they are barely enough in terms of social expectations and governmental demands. The comparison between top- 5 and bottom- 5 Ukrainian companies is shown in Fig. 7 in order to underline some key characteristics.

The comparison of top and bottom-5 Ukrainian companies proves that corporate social responsibil- ity cannot be reached without sustainable behavior. The more detailed audit of the companies' activity will show the real situation: either their activity is truly based on sustainable behavior, or they are just trying to disguise themselves as keeping to the general trend.

$\checkmark$ enerally, we can describe the sustainable path in international business as following (Fig. 8): in terms of sustainable development, companies have to make a decision: either to use corporate social responsibility as a tool for visualizing minimal changes and benefitting from mimicry in a short-term period, or they can choose a long-term strategy. The long-term strategy can be described as following: working on their brand value, they can form a sustainable behavior, which through corporate social responsibility leads to business value creation. 


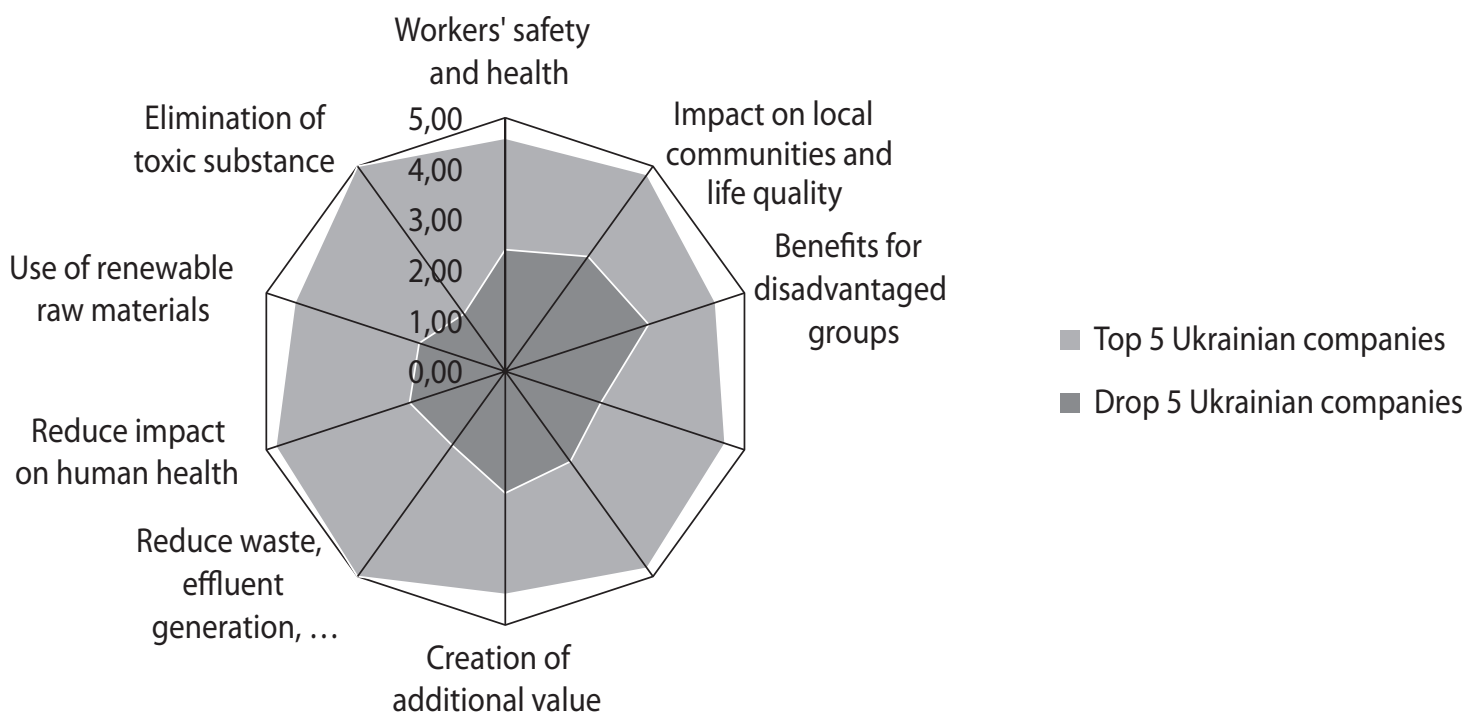

Fig. 7. Evaluation of average sustainable development components of bottom and top-5 Ukrainian companies

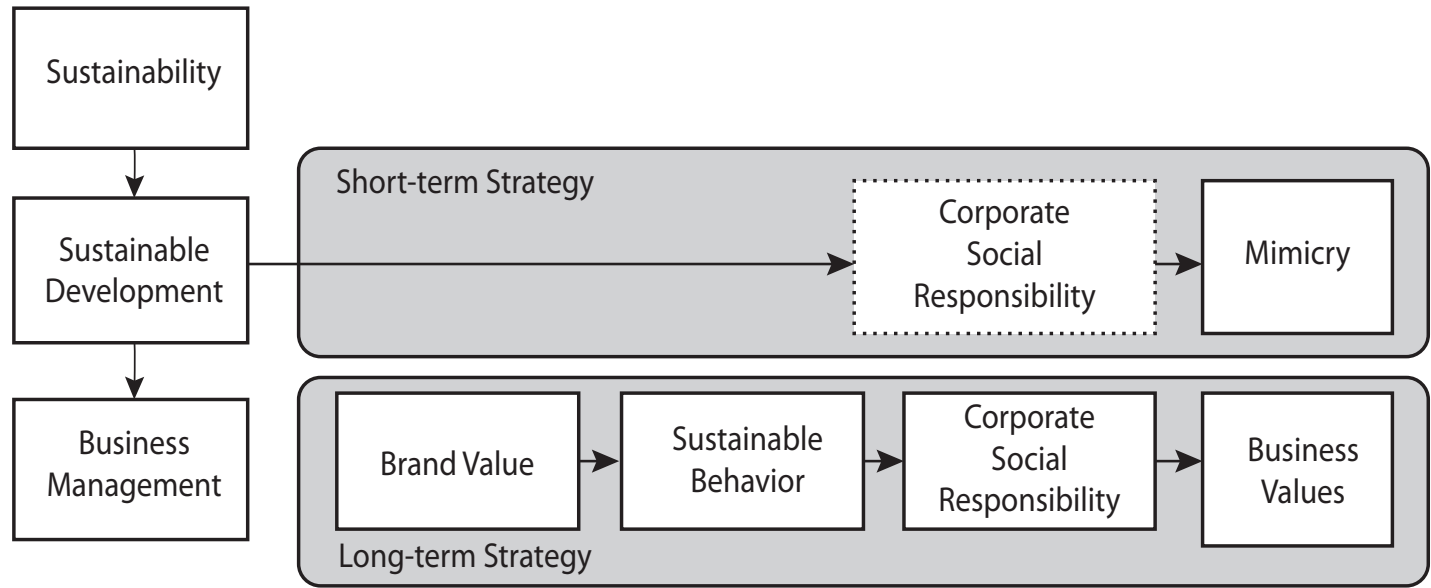

Fig. 8. The Sustainable Path in International Business

Evaluation process: as it was mentioned previously, sometimes, it is rather hard to tell the difference between mimicry and sustainable behavior.

A $\mathrm{s}$ we compared the results of global companies, all of them received maximum grades on each component. Although, to understand the difference between their activities, we have to proceed further and create a more detailed approach in order to assess their sustainability level.

In order to understand the process of sustainability ranking, we have to compare results from different rating agencies. Thus, we analyzed different criteria that are used in different ratings: DJSI, Global 100 Corporate Knights, Sustainalytics. All of them can be divided into 3 dimensions, but the importance of those dimensions will vary (Fig. 9).

In addition to the available categories, DJSI Ranking was also used for clarity. ESG Risk Rating includes
3 indicators (ESG risk level, management and vulnerability) and 2 additional components for clarity (ranking among industry representatives and the place in the global ranking of 13829 companies). ESG Risk Rating is based on "Sustainalytics" reports. It's a 25-year-old company that provides high-quality analytical environmental, social and governance (ESG) research, ratings and data to institutional investors and companies. Different sustainability ranking systems are shown in Fig. 10.

Thus, it is possible to draw a parallel between some DJSI/CK100 criteria and SDG tracker criteria. It also should be mentioned that in different sustainability assessment indicators (approaches), the major variable is different. For instance, Sustainable Development Goals and DJSI are more concentrated on social issues, while Global 100 CK points out that environmental issues are the prior goal to achieve. This information can be useful while making a combined list of indicators that can help to analyze the level of sustainability. to find the key weak 


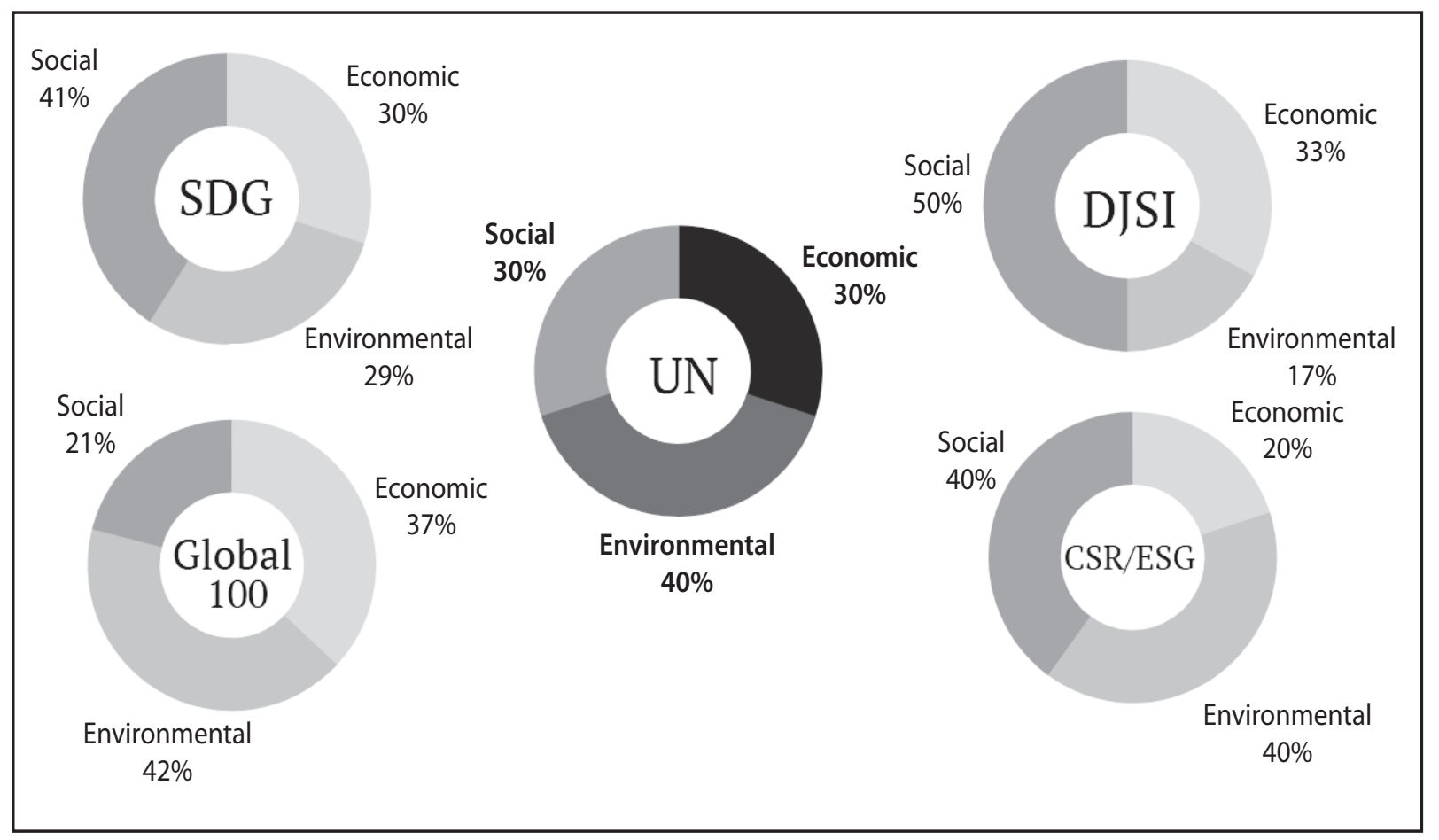

Fig. 9. Key components of different approaches to sustainability level assessment

\begin{tabular}{|c|c|c|c|c|c|c|c|c|c|c|}
\hline \multirow[b]{2}{*}{ Leaders Dow Jones } & \multirow[b]{2}{*}{ DJSI Ranking } & \multirow[b]{2}{*}{ SAM Industry } & \multirow[b]{2}{*}{ GK Industry } & \multirow[b]{2}{*}{$\begin{array}{c}\text { Global } 100 \\
\text { Knigts }\end{array}$} & \multirow[b]{2}{*}{ CSRHub } & \multicolumn{5}{|c|}{ ESG Risk Rating } \\
\hline & & & & & & $\begin{array}{l}\text { ESG Risk } \\
\text { Rate }\end{array}$ & $\begin{array}{l}\text { Industry } \\
\text { Rank }\end{array}$ & $\begin{array}{c}\text { Global } \\
\text { Rank (out } \\
\text { of 13829) }\end{array}$ & Exposure & Management \\
\hline Schneider Electric SE & Included & $\begin{array}{c}\text { Electrical Components } \\
\text { \& Equipment }\end{array}$ & $\begin{array}{c}\text { Industrial } \\
\text { Conglomerates }\end{array}$ & 29 & 98 & 17,4 & 8 out of 179 & 1822 & medium & strong \\
\hline UPM-Kymmene Oyj & Industry Leaders & $\begin{array}{l}\text { Paper \& Forest } \\
\text { Products }\end{array}$ & $\begin{array}{l}\text { Forestry and Paper } \\
\text { Products }\end{array}$ & 24 & 90 & 14,4 & 2 out of 79 & 866 & medium & strong \\
\hline Cisco Systems Inc & Industry Leaders & $\begin{array}{l}\text { Communications } \\
\text { Equipment }\end{array}$ & $\begin{array}{l}\text { Communications } \\
\text { Equipment }\end{array}$ & 4 & 94 & 12,5 & 66 out of 552 & 406 & low & strong \\
\hline $\begin{array}{l}\text { Hewlett Packard } \\
\text { Enterprise Co }\end{array}$ & Industry Leaders & $\begin{array}{c}\text { Computers \& } \\
\text { Peripherals and Office } \\
\text { Electronics }\end{array}$ & Computer Hardware & 15 & 89 & 11,7 & 44 out of 295 & 295 & low & strong \\
\hline Acciona SA & Not included & Electric Utilities & $\begin{array}{c}\text { Facilities and } \\
\text { Construction Services }\end{array}$ & 70 & 100 & 20,5 & 46 out of 612 & 3178 & high & strong \\
\hline
\end{tabular}

Fig. 10. Ranking of sustainability (combined example)

and strong sides of a company's activity. Some indicators that are used by different analytics are closely connected to others. For instance, "Elimination of toxic substances" (according to SDG Tracker), can be referred to VOC-, NOx-, SOx productivity as Global $100 \mathrm{CK}$ indicators; or "environmental reporting" by DJSI. Another point about DISI rating system is that it provides a certain correlation between criteria and weighting: some criteria will be more important and will have bigger influence on the final result and position of the company in the rating. The distribution of "values" of different criteria is shown in Fig. 11.

$\mathrm{S}$ imilar indicators used by different systems may demonstrate a one-way process for assessing sustainability. Considering the fact that the key indicators, which describe most of the relevant indicators in other systems, belong to the UN evaluation system, we can conclude that this particular approach to evaluation is the simplest and can be used by analysts for express or preliminary assessment. However, it should be noted that some of the indicators that are used by Dow Jones, CSR/ESG and Global 100 CK have no analogues in the UN assessment system. Some of them are very complex and are aimed to take into account a narrow range of factors of the company's activities. Finally, it can be stated that a detailed and fluent sustainable development assessment process should be based on a consolidated list of different indicators. This is the only way to make the final conclusion regarding the sustainability level, as well as draw conclusions about the investment appeal of a company. ESG ratings, while not creditworthy, help to identify criteria that can help companies to reduce their environmental risks and use their achievements in such rankings to demonstrate social responsibility, positively impact customer loyalty, and strengthen market position.

Based on the previous findings, we can create an advanced set of indicators and components of sustainable development level ( $T b l .3)$, based on SDG. 


\section{Corporate governance \\ Risk/crisis management \\ Codes of anti-corruption \\ Human-capital development \\ Talent attraction and retention \\ Labour practice indicators \\ Corporate citizenship \\ Social reporting \\ Environmental reporting}

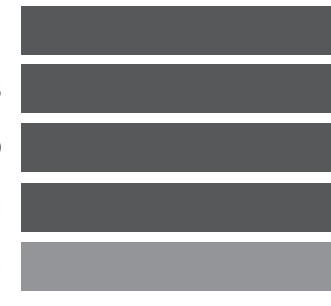

0

2

Fig. 11. The weight distribution of different criteria by DJSI

Table 3

Advanced indicators for assessing the sustainable development level

\begin{tabular}{|c|c|c|}
\hline Dimension & Primal evaluation & Advanced evaluation \\
\hline Economic & \multicolumn{2}{|c|}{$\begin{array}{l}\text { 1) creation of new markets and opportunities for sale growth; } \\
\text { 2) cost reduction through efficiency and improvements; } \\
\text { 3) creation of additional value }\end{array}$} \\
\hline Environmental & $\begin{array}{l}\text { 1) reduce waste, effluent generation, emission } \\
\text { into environment; } \\
\text { 2) elimination of toxic substances; } \\
\text { 3) use of renewable raw materials }\end{array}$ & $\begin{array}{l}\text { 1) Waste productivity } \\
\text { 2) VOC productivity } \\
\text { 3) NOx productivity } \\
\text { 4) SOx productivity } \\
\text { 5) Energy productivity } \\
\text { 6) Water productivity }\end{array}$ \\
\hline Social & $\begin{array}{l}\text { 1) workers' safety and health; } \\
\text { 2) reduce impact on human health; } \\
\text { 3) benefits for disadvantaged groups; } \\
\text { 4) impact on local communities, life quality }\end{array}$ & $\begin{array}{l}\text { 1) CEO-average employee pay } \\
\text { 2) Employee turnover } \\
\text { 3) Non-males in executive management } \\
\text { 4) Non-males on boards } \\
\text { 5) Racial diversity among executive management } \\
\text { 6) Racial diversity on the board of directors } \\
\text { 7) Talent attraction and retention } \\
\text { 8) Corporate citizenship } \\
\text { 9) Social reporting } \\
\text { 10) Philanthropy } \\
\text { 11) Labor practice indicators } \\
\text { 12) Human capital development } \\
\text { 13) Injuries } \\
\text { 14) Fatalities } \\
\text { 15) Paid sick leave }\end{array}$ \\
\hline
\end{tabular}

It is important to mention that the whole concept of today's discussion of sustainability ranking systems is centered around business value. This fact can be explained by the vital significance of the UN role in the sustainability development concept. For example, the Global Agreement of United Nations has proclaimed 10 principles that were promptly accepted by numerous companies all over the world (more than 12765 companies in 160 countries) and became main features of their brandand marketing strategies.

When it comes to the point of the future discussion, we have the following situation: the world com- munity is coming up with the generalized concept of further development of our society, economics and environmental policy, that is accepted by stakeholders and becoming the basis for assessing the success and effectiveness of activities in the field of sustainable development. As it was said previously, the final converter between subjective acceptance of companies' performance and objective rating system is ESG audit companies, because no one else can assess risks and convert them to business value. That means that ESG becomes the business value indicator. The role of ESG and CSR can be schematized in Fig. 12. 


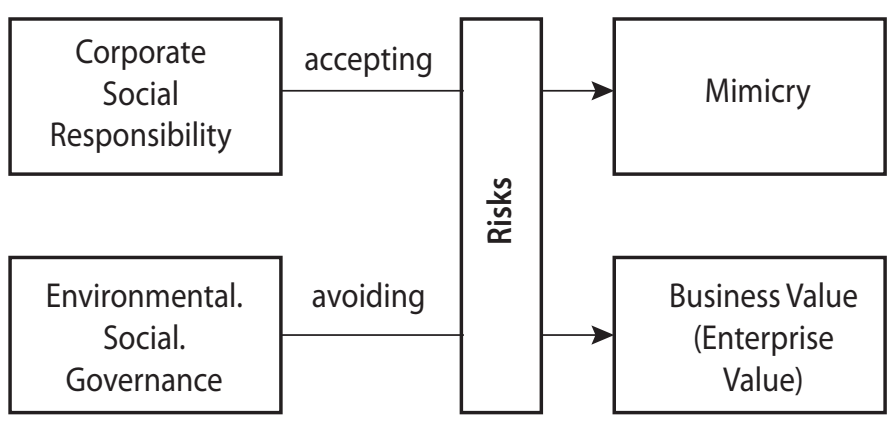

Fig. 12. CSR and ESG roles in the sustainable development concept

It should be noted that both CSR and ESG concepts are being used in order to maximize the objectivity of assessing the sustainable development level. The main difference between them is that the ESG concept helps to analyze and predict the future of companies' activity. That is because they take into account risk system and put a great value into this indicator. The mimicry shows up when companies are trying to pass off their actual activity as the one focused on sustainable development

\section{CONCLUSIONS}

Having analyzed the specifics of sustainable development, corporate social responsibility and ESG concepts, we can now explain the difference between them. Due to the fact that all the three concepts have the same origins, they have been developed in order to systematize the process of sustainable development level assessment.

While comparing Ukrainian and global sustainable companies, two main discoveries have been made. Firstly, the situation in Ukrainian market is more positive than it was expected: top Ukrainian companies show good trends in terms of implementing corporate social responsibility. Thus, on comparing their results with other Ukrainian companies from further positions, it has become clear that some of the companies that are present in sustainable development ranks show signs of mimicry. Though they are active on social media, their reports don't provide enough evidences to prove that their level of corporate social responsibility corresponds to their ranking position. Secondly, while analyzing global companies, it is hard to make a final statement about their exact level of sustainable development. For instance, all the 5 companies chosen for the research have maximum grades on each component. That is why, for more detailed sustainable development level assessment, the primary scale of components is not enough (the one based on UN Global Compact and Sustainable Development Goals).

Due to that purpose, a complementary set of components and indicators that could help analytics to make more precise ranking has been made. This set was based on both SDG and UN Global Compact indicators with an addition from the most popular and respected rankings of sustainable development: DISI and Corporate Knights Global 100. Although they have some common components, the cumulative result occurs due to the difference between their approaches and primary tasks. For instance, Dow Jones rating system pays more attention to economic and social dimensions and almost ignores environmental components. However, the issue of an integrated set of components requires further research. It is necessary to mention that knowing the features of assessing the level of sustainable development, that is done by different analytics, we can make more accurate statements about the difference between real corporate social responsibility and mimicry.

$\mathrm{F}$ inally, some of Ukrainian companies do rely on the UN Global Compact and SDG; however, the real situation is disguised under the general tendencies in society. The business activity of these businesses is aimed not at increasing business value, but at getting short-term results. They are guided by the requirements of society and implement changes at a sufficient level for perception in the context of marketing communications. It proves that corporate social responsibility is not possible without sustainable behavior based on business values. Thus, the process and specifics of business values creation is another topic that requires further research.

\section{LITERATURE}

1. Borowy I. Defining Sustainable Development for Our Common Future: A History of the World Commission on Environment and Development (Brundtland Commission). Routledge, 2014. $256 \mathrm{p}$.

2. O'Neill G. D., Hershauer J. C., Jr., Golden J. S. The Cultural Context of Sustainability Entrepreneurship. Greener Management International. 2006. No. 55. P. 33-46. URL: http://www.jstor.org/stable/greemanainte.55.33

3. Mariani M. M., Buhalis D., Czakon W., Vitouladiti 0 . Tourism Management, Marketing, and Development: Performance, Strategies, and Sustainability. New York: Palgrave-Macmillan, 2015. 301 p.

4. Corona B. et al. Towards sustainable development through the circular economy - A review and critical assessment on current circularity metrics / Corona B., Shen Li, Reike D., Carreón J. R., Worrell E. Resources, Conservation and Recycling. 2019. Vol. 151. Art. 104498. DOI: https://doi.org/10.1016/j.resconrec.2019.104498 
5. Sudolska A., Lis A. Sustainable Enterprise and Sustainable Organisation: Mapping the Research Field with Keywords Analysis. Journal of Corporate Responsibility and Leadership. 2017. Vol. 4. Iss. 3. P. 155-168.

DOI: http://dx.doi.org/10.12775/JCRL.2017.022

6. Giddings B., Hopwood B., Brien G. O. Environment, economy and society: Fitting them together into sustainable development. Sustainable Development. 2002. Vol. 10. Iss. 4. P. 187-196.

DOI: https://doi.org/10.1002/sd.199

7. Liu X. et al. Navigating Transitions for Sustainable Infrastructures - The Case of a New High-Speed Railway Station in Jingmen / Liu X., Schraven D., De Bruijne M., Do Jong M., Hertogh M. China. Sustainability. 2019. Vol. 11. Iss. 15. Art. 4197.

DOI: https://doi.org/10.3390/su11154197

8. Assefa G. Ã., Frostell B. Social sustainability and social acceptance in technology assessment: A case study of energy technologies. Technology in Society. 2007. Vol. 29. Iss. 1. P. 63-78.

DOI: https://doi.org/10.1016/j.techsoc.2006.10.007

9. Codagnone C., Misuraca G., Savoldelli A., Lupiañez-Villanueva F. Institutional isomorphism, policy networks, and the analytical depreciation of measurement indicators: The case of the EU e-government benchmarking. Telecommunications Policy. 2015. Vol. 39. Iss. 3-4. P. 305-319.

DOI: https://doi.org/10.1016/j.telpol.2015.01.005

10. Joseph C., Taplin R. Local government website sustainability reporting: A mimicry perspective. Social Responsibility Journal. 2012. Vol. 8.Iss. 3. P. 363-372. DOI: 10.1108/17471111211247938

11. Di Maggio P. J., Powell W. W. The Iron Cage Revisited: Institutional Isomorphism and Collective Rationality in Organisational Fields. American Sociological Review. 1983. Vol. 48. No. 2. P. 147-160.

DOI: https://doi.org/10.2307/2095101

12. Hannan M. T., Freeman J. The Population Ecology of Organizations. American Journal of Sociology. 1977. Vol. 82. No. 5. P. 929-964. URL: https://www.jstor.org/ stable/2777807

13. Kauppi K. Extending the use of institutional theory in operations and supply chain management research: Review and research suggestions. International Journal of Operations \& Production Management. 2013. Vol. 33. Iss. 10. P. 1318-1345.

DOI: 10.1108/IJOPM-10-2011-0364.

14. Anđić Dunja, and Sanja Tatalović Vorkapić. Interdisciplinary Approaches to Sustainable Development in Higher Education: A case Study from Croatia. Handbook of Research on Pedagogical Innovations for Sustainable Development. IGI Global, 2014. P. 67-115. DOI: 10.4018/978-1-4666-5856-1.ch005.

15. Kshetri N. The development of market orientation: A consideration of institutional influence in China. Asia Pacific Journal of Marketing and Logistics. 2009. Vol. 21. Iss. 1. P. 19-40. DOI: $10.1108 / 13555850910926227$

16. Aguilera R., Rupp D. E., Williams C. A., Ganapathi J. Putting the $S$ back in corporate social responsibility A multi-level theory of social change in organizations. Academy of Management Review. 2007. Vol. 32. No. 3. P. 836-863.

DOI: https://doi.org/10.5465/amr.2007.25275678
17. Белоусов К. Ю. Мимикрия социально-ответственғ ного поведения как актуальная проблема современного этапа развития КСО // Сборник тезисов Семнадцатой международной конференции молодых ученых-экономистов «Предпринимательство и реформы в России» (г. Санкт-Петербург, 24-25 ноября 2011 г.). Санкт-Петербург, 2011. С. 327-328.

18. Благов Ю. Е. Концепция корпоративной социальной ответственности и стратегическое управление. Российский журнал менеджмента. 2004. Т. 2. № 3. C. 17-34. URL: https://ecsocman.hse.ru/data/058/625/ 1219/x233_017_034.pdf

\section{REFERENCES}

Aguilera, R. et al. "Putting the S back in corporate social responsibility-A multi-level theory of social change in organizations". Academy of Management Review, vol. 32, no. 3 (2007): 836-863.

DOI: https://doi.org/10.5465/amr.2007.25275678

Assefa, G. A., and Frostell, B. "Social sustainability and social acceptance in technology assessment: A case study of energy technologies". Technologyin Society, vol.29, no. 1 (2007): 63-78.

DOI: https://doi.org/10.1016/j.techsoc.2006.10.007

Belousov, K. Yu. "Mimikriya sotsialno-otvetstvennogo povedeniya kak aktualnaya problema sovremennogo etapa razvitiya KSO" [Mimicry of Socially Responsible Behavior as an Urgent Problem of the Current Stage of CSR Development]. Predprinimatelstvo i reformy $v$ Rossii. St. Petersburg, 2011. 327-328.

Blagov, Yu. Ye. "Kontseptsiya korporativnoy sotsialnoy otvetstvennosti i strategicheskoye upravleniye" [The Concept of Corporate Social Responsibility and Strategic Management]. Rossiyskiy zhurnal menedzhmenta, vol. 2, no. 3 (2004): 17-34. https://ecsocman.hse.ru/ data/058/625/1219/x233_017_034.pdf

Borowy, I. Defining Sustainable Development for Our Common Future: A History of the World Commission on Environment and Development (Brundtland Commission). Routledge, 2014.

Codagnone, C. et al. "Institutional isomorphism, policy networks, and the analytical depreciation of measurement indicators: The case of the EU e-government benchmarking". Telecommunications Policy, vol. 39, no. 3-4 (2015): 305-319.

DOI: https://doi.org/10.1016/j.telpol.2015.01.005

Corona, B. et al. "Towards sustainable development through the circular economy - A review and critical assessment on current circularity metrics". Resources, Conservation and Recycling, art. 104498, vol. 151 (2019).

DOI: https://doi.org/10.1016/j.resconrec.2019.104498

Di Maggio, P. J., and Powell, W. W. "The Iron Cage Revisited: Institutional Isomorphism and Collective Rationality in Organisational Fields". American Sociological Review, vol. 48, no. 2 (1983): 147-160. DOI: https://doi.org/10.2307/2095101

Dunja, A., and Tatalovic Vorkapic, S. "Interdisciplinary Approaches to Sustainable Development in Higher Education: A case Study from Croatia". In Handbook of Research on Pedagogical Innovations for Sustainable Development, 67-115. IGI Global, 2014. DOI: 10.1108/IJOPM-10-2011-0364 
Giddings, B., Hopwood, B., and Brien, G. O. "Environment, economyandsociety:Fittingthemtogetherintosustainable development". Sustainable Development, vol. 10, no. 4 (2002): 187-196.

DOI: https://doi.org/10.1002/sd.199

Hannan, M. T., and Freeman, J. "The Population Ecology of Organizations". American Journal of Sociology, vol. 82, no. 5 (1977): 929-964. https://www.jstor.org/stable/2777807

Joseph, C., and Taplin, R. "Local government website sustainability reporting: A mimicry perspective". Social Responsibility Journal, vol. 8, no. 3 (2012): 363-372. DOI: $10.1108 / 17471111211247938$

Kauppi, K. "Extending the use of institutional theory in operations and supply chain management research: Review and research suggestions". International Journal of Operations \& Production Management, vol. 33, no. 10 (2013): 1318-1345.

DOI: 10.1108/IJOPM-10-2011-0364

Kshetri, N. "The development of market orientation: A consideration of institutional influence in China".
Asia Pacific Journal of Marketing and Logistics, vol. 21, no. 1 (2009): 19-40.

DOI: $10.1108 / 13555850910926227$

Liu, X. "Navigating Transitions for Sustainable Infrastructures - The Case of a New High-Speed Railway Station in Jingmen". Sustainability, art. 4197, vol. 11, no. 15 (2019).

DOI: https://doi.org/10.3390/su11154197

Mariani, M. M. et al. Tourism Management, Marketing, and Development: Performance, Strategies, and Sustainability. New York: Palgrave-Macmillan, 2015.

O'Neill, G. D., Hershauer, J. C. Jr., and Golden, J. S. "The Cultural Context of Sustainability Entrepreneurship". Greener Management International, no. 55 (2006): 33-46. http://www.jstor.org/stable/greemanainte.55.33

Sudolska, A., and Lis, A. "Sustainable Enterprise and Sustainable Organisation: Mapping the Research Field with Keywords Analysis". Journal of Corporate Responsibility and Leadership, vol. 4, no. 3 (2017): 155-168. DOI: http://dx.doi.org/10.12775/JCRL.2017.022

УДК 658.3

JEL: I19; M12; M50; M59

DOI: https://doi.org/10.32983/2222-4459-2021-11-439-446

\title{
МОТИВАЦІЯ ПЕРСОНАЛУ ПРИ ФОРМУВАННІ ТА РОЗВИТКУ КАДРОВОГО ПОТЕНЦІАЛУ ЗАКЛАДІВ ОХОРОНИ ЗДОРОВ'Я УКРАЇНИ
}

\author{
๑2021 ОСТАПЧУК Т. П., БІРЮЧЕНКО С. Ю., ЛЕБЕДИНЕЦЬ Л. Є., ПАЛІЙ О. В., СЛУЧИЧ Н. В.
}

УДК 658.3

JEL: I19; M12; M50; M59

\section{Остапчук Т. П., Бірюченко С. Ю., Лебединець Л. Є., Палій О. В., Случич Н. В. Мотивація персоналу при формуванні та розвитку кадрового потенціалу закладів охорони здоров'я України}

Мотивація персоналу розглядається як основний елемент його розвитку. Узагальнено теоретичний зміст поняття «кадровий потенціал підприємства» та визначено особливості та проблеми формування кадрового потенціалу в закладах охорони здоров'я. Адже правильно побудована, оптимізована та заснована на реальних потребах персоналу система мотивації успішно поєднує стратегічні цілі установи, особисті інтереси працівників і першочергові потреби населення, що забезпечується закладами охорони здоров'я. Акцентовано увагу на постійному розвитку кадрового потенціалу установи для забезпечення його відповідності умовам діяльності, адаптації до зовнішнього середовища та самореалізації. Доведено, що велике значення під час формування та розвитку кадрового потенціалу відводиться мотивації працівників і визначенню мотивуючих і демотивуючих факторів розвитку. Мотивацію персоналу закладів охорони здоров'я розглянуто в розрізі трьох ії видів: матеріальної, нематеріальної (моральної) та адміністративної, а також проведено порівняльну характеристику цих видів мотивації в медичних установах за кордоном. Визначено специфіку роботи медичних працівників, яка впливає на їх мотивацію, оскільки значна кількість працівників медичних установ стикається із постійною негативною оцінкою ї роботи, що призводить до профресійного вигорання та відсутності мотивації для подальшоі роботи. Ця криза посилюється недостатнім рівнем фінансового забезпечення медичних працівників при постійному посиленні вимог до якості їх роботи. Запропоновано закцентувати увагу уряду та керівників медичних установ на поєднанні матеріальних і нематеріальних засобів мотивації, уникненні демотиваційних чинників для забезпечення ефективності формування та розвитку кадрового потенціалу медичного закладу. Ключові слова: кадровий потениіал, мотивачія, види мотиваиії, розвиток, заклади охорони здоров'я.

Табл.: 2. Бібл.: 19.

Остапчук Тетяна Петрівна - доктор економічних наук, професор, завідувачка кафедри менеджменту і підприємництва, Державний університет «Житомирська політехніка» (вул. Чуднівська, 103, Житомир, 10005, Україна)

E-mail: ostapchuk-a@ukr.net

ORCID: https://orcid.org/0000-0001-9623-0481

Бірюченко Світлана Юріївна - кандидат економічних наук, доцент кафедри менеджменту і підприємництва, Державний університет «Житомирська політехніка» (вул. Чуднівська, 103, Житомир, 10005, Україна)

E-mail: sy_biryuchenko@ukr.net

ORCID: https://orcid.org/0000-0002-6340-8607

Лебединець Лариса Євгенівна - магістрантка, Державний університет «Житомирська політехніка» (вул. Чуднівська, 103, Житомир, 10005, Україна) Палій Оксана Вікторівна - магістрантка, Державний університет «Житомирська політехніка» (вул. Чуднівська, 103, Житомир, 10005, Україна) Случич Наталія Володимирівна - магістрантка, Державний університет «Житомирська політехніка» (вул. чуднівська, 103, Житомир, 10005, Україна) 